\title{
Interspecific variation in leaf pigments and nutrients of five tree species from a subtropical forest in southern Brazil
}

\author{
MÁRCIA BÜNDCHEN ${ }^{1}$, MARIA REGINA T. BOEGER ${ }^{2}$, CARLOS B. REISSMANN ${ }^{3}$ and KELLY M. GERONAZZO ${ }^{4}$ \\ ${ }^{1}$ Instituto Federal de Educação, Ciência e Tecnologia do Rio Grande do Sul (IFRS), \\ Rua Coronel Vicente, 281, Centro, 90030-040 Porto Alegre, RS, Brasil \\ ${ }^{2}$ Programa de Pós-Graduação em Ecologia e Conservação, Setor de Ciências Biológicas, \\ Universidade Federal do Paraná, Caixa Postal 19031, 81531-990 Curitiba, PR, Brasil \\ ${ }^{3}$ Departamento de Solos e Engenharia Agrícola, Setor de Ciências Agrárias, Universidade Federal \\ do Paraná, Rua dos Funcionários, 1540, 80035-050 Juvevê, Curitiba, PR, Brasil \\ ${ }^{4}$ Universidade Estadual do Centro Oeste, PR 103, Km 157, 84500-000 Irati, PR, Brasil
}

Manuscript received on November 7, 2014; accepted for publication on March 3, 2015

\begin{abstract}
The purpose of this study was to analyze the seasonal variation in the nutrient and pigment content of leaves from five tree species - of which three are perennial (Cupania vernalis, Matayba elaeagnoides and Nectandra lanceolata) and two are deciduous (Cedrela fissilis and Jacaranda micrantha) - in an ecotone between a Deciduous Seasonal Forest and a Mixed Ombrophilous Forest in the state of Santa Catarina, Brazil. Leaf samples were collected in the four seasons of the year to determine the content of macronutrients (N, K, P, Mg, Ca, S) and photosynthetic pigments ( $\mathrm{Chl}_{a}, \mathrm{Chl}_{b}, \mathrm{Chl}_{t o t}, \mathrm{Car}_{t o t}, \mathrm{Chl}_{a}: \mathrm{Chl}_{b}$ and $\mathrm{Car}_{\text {tot }}: \mathrm{Chl}_{\text {tot }}$ ). The principal component analysis showed that leaf pigments contributed to the formation of the first axis, which explains most of the data variance for all species, while leaf nutrient contribution showed strong interspecific variation. These results demonstrate that the studied species have different strategies for acquisition and use of mineral resources and acclimation to light, which are determinant for them to coexist in the forest environment.
\end{abstract}

Key words: chlorophyll, Araucaria forest, Deciduous Forest, macronutrients.

\section{INTRODUCTION}

Plant distribution is associated with environmental factors, and its adaptation to a particular type of environment involves optimizing the acquisition and use of resources, specifically light and nutrients. Considering that resource availability varies in the interior of forests, the capacity of

Correspondence to: Márcia Bündchen

E-mail: marcia.bundchen@poa.ifrs.edu.br each species to use them, largely determines its competitive abilities (Grime 1977). Thus, leaf physiological traits, such as the content of nutrients and photosynthetic pigments, reflect a plant's light capture performance; the study of such characteristics provides clues to the understanding of the functional ecology of plants in different ecosystems (Poorter 2009).

Environmental conditions change throughout the day and seasons. Consequently, each habitat 
presents a combination of independent environmental variables whose intensity varies during the year (Pierce et al. 2005). Climate seasonality is an important determinant of phenological events, having a direct impact on metabolic and regulating processes such as germination, sprouting, senescence, flowering, and fruiting (Taiz and Zeiger 2013). Plant response to seasonality effects has been widely studied in northern ecosystems (Chapin III 1980), Mediterranean (Valladares et al. 2000), and other strongly seasonal ecosystems, such as the Brazilian cerrado (Carvalho et al. 2007), where the vegetation is subjected to severe resource constraints during a period of the year and shows morphophysiological variations. The ecophysiology of plants from subtropical forests, where the transition between seasons is gradual, has not been studied in depth up until now, and general data on subtropical forests are still scarce.

The effects of environmental parameters, such as light quality and intensity, and nutrient availability in the soil, have been characterized mainly through testing under controlled conditions, using mostly seedlings and saplings - very few researches result from the analysis of adult trees in their habitats. As a consequence, the models and interpretations that are generated are at odds with actual responses by plants in natural environments. This study, conducted with tree species from an interface area between two forest formations in southern Brazil, was concerned with analyzing whether: $i$. trees respond to changing seasons with altered content of leaf nutrients and pigments and $i$ i. there is a correlation between the content of leaf nutrients and pigments.

\section{MATERIALS AND METHODS}

The study was carried out in "Parque Natural Municipal do Rio do Peixe", located in the municipality of Joaçaba, state of Santa Catarina, Brazil $\left(27^{\circ} 10^{\prime} 41^{\prime \prime} \mathrm{S}\right.$ and $51^{\circ} 30^{\prime} 17^{\prime} \mathrm{O}, 770 \mathrm{~m}$ of altitude), and consist of a forest fragment with 200 ha of Atlantic Forest biome (IBGE 1990) in a transition area between the Deciduous Seasonal Forest (or FED - Floresta Estacional Decidual) and the Mixed Ombrophilous Forest (or FOM - Foresta Ombrófila Mista). The area is home to species from both forest typologies, and one of the few remnants of the region's original vegetation (Raimundo 2003).

The Deciduous Seasonal Forest (FED) stretches along the Uruguay River basin, in southern Brazil (Klein 1978, Leite 2002) and, according to Ruschel et al. (2007), it is the most endangered forest ecosystem in the south of Brazil, demanding immediate efforts towards its conservation. The Mixed Ombrophilous Forest (FOM), which originally stretched across a major portion of the southern region, is currently highly fragmented. In the regions with altitude around $600 \mathrm{~m}, \mathrm{FOM}$ and FED meet, forming an area of ecological tension, or ecotone, which enables the mixing of species from both forest physiognomies and bringing more diversity to these transition areas (Leite 2002).

The distribution area of FED and its interface with FOM is typically ombrophilous, with no dry periods and regular rainfall. Thermal rates determine two quite distinct periods, one centered in summer, with average temperature equal to or higher than $20^{\circ} \mathrm{C}$, and another centered in winter, with average temperature equal to or below $15^{\circ} \mathrm{C}$ (Leite 2002).

The soil was determined to be "Nitossolo Bruno" following dos Santos et al. (2006), with high content of clay $(>60 \%)$, acid $\mathrm{pH}(3.9-5.0)$, organic matter (3.3-6\%), P (2.3-4.8 mg dc $\left.{ }^{-3}\right), \mathrm{K}$ (21->400 $\left.\mathrm{mg} \mathrm{dc}^{-3}\right)$, exchangeable $\mathrm{Ca}(0.1-6.1 \mathrm{cmol}$ $\left.\mathrm{dm}^{-3}\right)$, exchangeable $\mathrm{Mg}\left(0.1-2.8 \mathrm{cmol} \mathrm{dm}^{-3}\right)$, and extractable $\mathrm{S}\left(8.8-25 \mathrm{mg} \mathrm{dc}^{-3}\right)$. More details about soil classification can be found in Bündchen et al. (2013).

Within the study area, five tree species occurring in both FED and FOM were selected: Cupania 
vernalis Cambess. (Sapindaceae), perennial, heliophytic, with pinnately compound leaves; Matayba elaeagnoides Radlk. (Sapindaceae), perennial, mesophytic, pinnately compound leaves; Nectandra lanceolata Nees \& Mart. (Lauraceae), perennial, mesophytic, with simple leaves; Cedrela fissilis Vell. (Meliaceae), deciduous, heliophytic, with pinnately compound leaves; and Jacaranda micrantha Cam. (Bignoniaceae), deciduous, heliophytic, with compound leaves (Klein 1978). These species were identified by taxonomy experts from the Museu Botânico de Curitiba, state of
Paraná. All trees were 15 to $19 \mathrm{~m}$ high. The study was conducted in 12 months, and samples were collected every quarter in each season of the year. Climate variables for the period are in agreement with the typical averages for the period, and, for analysis purposes, fall/winter were classified as "cold period" and spring/summer were classified as "warm period" (Table I), following Leite (2002). For each species, five specimens in the canopy were marked and used for the collection of mature leaves which were fully expanded and fully exposed to sunlight.

TABLE I

Climatic parameter averages: rainfall, radiation, average temperature and classification of cold and warm period.

\begin{tabular}{ccccc}
\hline Season & Rainfall $(\mathrm{mm})$ & Radiation $\left(\mathrm{W} / \mathrm{m}^{2}\right)$ & Temperature $\left({ }^{\circ} \mathrm{C}\right)$ & Period \\
\hline Autumn & 86.3 & 306.7 & 15.2 & Cold \\
Winter & 262.4 & 270.4 & 14.1 & \\
Spring & 193.5 & 382.4 & 20.8 & Warm \\
Summer & 207.9 & 376.6 & 22.2 & \\
\hline
\end{tabular}

In order to determine the nutrients [Nitrogen (N), Phosphorus (P), Potassium (K), Calcium (Ca), Magnesium $(\mathrm{Mg})$ and Sulfur $(\mathrm{S})$ ], fully expanded mature leaves were collected from each specimen in the canopy (a compound sample $\mathrm{x}$ five species $\mathrm{x}$ five specimens $\mathrm{x}$ four seasons), washed with deionized water, dehydrated in an oven at $60{ }^{\circ} \mathrm{C}$ and crushed. The samples were sent to the Laboratory of Fertility of Instituto Agronômico de Campinas (IAC-SP) and subjected to nitric-perchloric digestion. All element concentrations were estimated using argon plasma optical emission spectrometry (ICP OES). Nitrogen was measured using the Kjeldahl method.

Pigments were extracted using $80 \%$ acetone on fresh leaf samples (five leaves $\mathrm{x}$ five specimens $\mathrm{x}$ five species $\mathrm{x}$ four collections) and measured with a spectrophotometer. The content of chlorophyll $a$ $(\mathrm{Chl})$, chlorophyll $b\left(\mathrm{Chl}_{b}\right)$ and total chlorophyll $\left(\mathrm{Chl}_{\text {tot }}\right)$ was determined as described by Porra et al. (1989), and total carotenoids $\left(\mathrm{Car}_{\text {tot }}\right)$ followed Lichtenthaler and Wellburn (1985). Based on these data, the chlorophyll $a$ :chlorophyll $b$ ratio $\left(\mathrm{Chl}_{a}: \mathrm{Chl}_{b}\right)$ and the total carotenoids:total chlorophyll ratio $\left(\mathrm{Car}_{t o t}: \mathrm{Chl}_{\text {tot }}\right.$ ) were calculated.

The experimental design was entirely randomized with a factor (season), of which the other variables (pigments and nutrients) were considered to be dependent. Thus, the five species were analyzed individually.

Principal component analyses (PCAs) were performed in order to describe the data by identifying the most representative variables and the ones that presented a higher correlation coefficient. Based on this correlation structure, shown by the PCA axes, we tried to identify the variables that could explain a higher percentage of data than the individual measures on the field. In this context, we decided to evaluate the score of the most representative PCA axes by applying one- 
way ANOVA. Variance homogeneity was verified previously by applying Bartlett's test at 5\% (Zar 1999). The Kruskal-Wallis test (nonparametric) was used when the premise of using ANOVA (homogeneity of variances) could not be met. To test gaussianity, we used the Kolmogorov-Smirnov test. The latent root criterion (Kaiser) was applied to determine the minimum number of axes to be considered. In this case, only eigenvalues greater than one were considered relevant (Johnson and Wichern 1998) and variable correlation was verified by using Spearman's correlation test. In all analyses, the results were considered significant at $p<0.05$. All statistical analyses were performed using Statistica software (Statistica, version 7.0 Statsoft Inc., USA).

\section{RESULTS}

Most foliar nutrient concentrations showed pronounced interspecific variation. Among species, $\mathrm{Mg}$ presented the highest variation, while $\mathrm{N}$ presented the lowest variation. Nitrogen and $\mathrm{P}$ from the leaves of $J$. micranta, $\mathrm{K}$ from $N$. lanceolata, $\mathrm{Ca}$ from C. fissilis, $\mathrm{Mg}$ from M. elaeagnoides and $\mathrm{S}$ from $C$. vernalis showed the highest variation among seasons. For pigments, total chlorophyll presented highest variation and chlorophyll the lowest. Among seasons, $\mathrm{Chl}_{a}$ showed the highest variation from $M$. elaeagnoides leaves, $\mathrm{Chl}_{b}$ and total chlorophyll showed the highest variation from $J$. micrantha, carotenoids showed the higher variation from $N$. lanceolata. Compared to deciduous trees, perennial species presented a higher variation, among seasons, for $\mathrm{P}, \mathrm{K}, \mathrm{Mg}, \mathrm{S}$, chlorophyll ${ }_{a}$, total chlorophyll and carotenoids.

Principal component analysis (PCA) showed that the evaluated leaf parameters (photosynthetic pigments and nutrients) contribute differently to axis formation in the species on the FED/FOM interface. In general terms, pigments contributed to the first axes, explaining most of the data variance. Nutrients, on the other hand, correlated with the other axes, explaining a smaller percentage of information.

In $N$. lanceolata (Fig. 1a), the first four axes explain $89.4 \%$ of the variance, and $40.7 \%$ of data variance can be attributed to the first axis. In $M$. elaeagnoides (Fig. 1b), 81.3\% of the variance was determined by the first three axes, while the first axis was responsible for $38 \%$ of data variance. In C. vernalis (Fig. 1c), $89.7 \%$ of data variance was explained by four axes, $36.7 \%$ of which can be attributed to the first axis. In J. micrantha (Fig. 1d), four axes determine $90.1 \%$ of the information, of which $36.8 \%$ are explained by the first axis.

In these four species, variables $\mathrm{Chl}_{a}, \mathrm{Chl}_{b}, \mathrm{Chl}_{\text {tot }}$ and $\mathrm{Chl}_{\text {tot }}: \mathrm{Car}_{\text {tot }}$ are strongly correlated with the first axis. The $\mathrm{Chl}_{a}: \mathrm{Chl}_{b}$ ratio positively correlated with the first axis in the perennial species and C. fissilis. On the other hand, the correlation of nutrients with the first axis was lower and showed a strong specific characteristic (Table II).

In C. fissilis (Fig. 1e), 84\% of the variance can be explained by the first three axes (first axis = $55.8 \%$ ). In this species, most variables - except $\mathrm{N}$, $\mathrm{Car}_{\text {tot }}$ and $\mathrm{Chl}_{\text {tot }}: \mathrm{Car}_{\text {tot }}$ - showed a strong contribution to the first axis, unlike the other species in which the contribution of pigments and nutrients with greater weight was distributed among the functions that represent different axes (Table II).

The correlation coefficients that correspond to the second axis (Table II) were positive for K, P and $\mathrm{S}$ in $N$. lanceolata, $\mathrm{K}$ and $\mathrm{P}$ in $M$. elaeagnoides and $\mathrm{N}, \mathrm{K}$ and $\mathrm{P}$ in $C$. vernalis. Among the deciduous species, J. micrantha showed $\mathrm{N}$ and $\mathrm{P}$ negatively correlated with the second axis, and in $C$. fissilis only $\mathrm{N}$ was negatively correlated with the second axis (Table II).

The ANOVA carried out with the scores, showed that seasonal differences are reflected in the participation of pigments and nutrients in axis formation for each species studied (Table III). As previous studies had shown, $N$. lanceolata, $M$. elaeagnoides, $C$. vernalis and $J$. micrantha present 


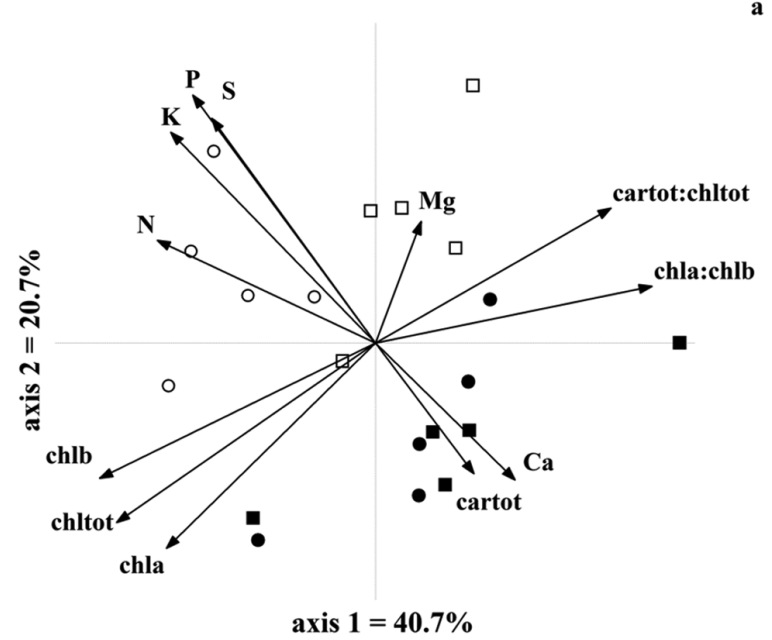

c

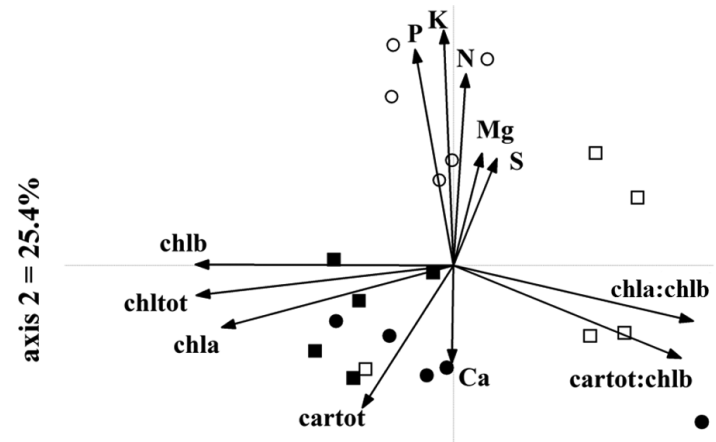

axis $1=\mathbf{3 7 . 6} \%$

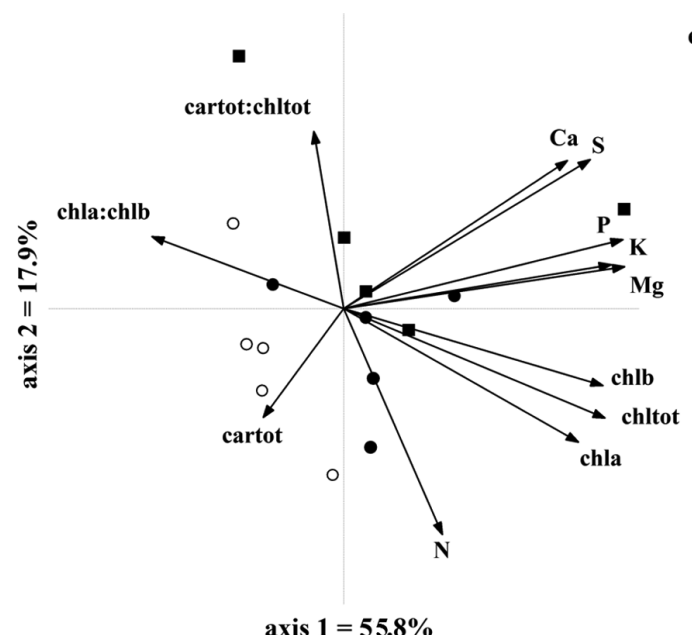

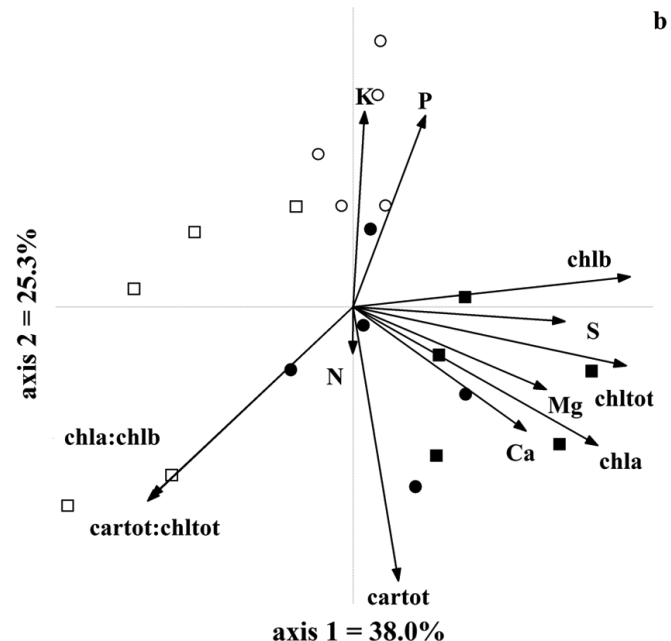

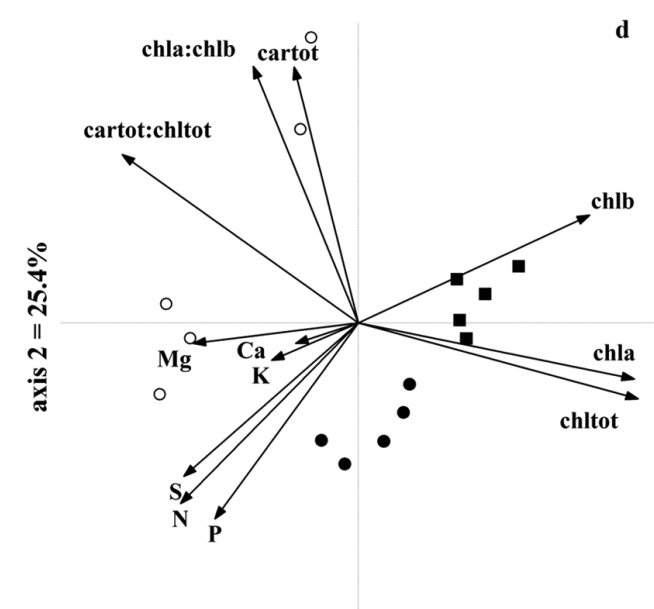

axis $1=36.8 \%$

(⿸丆口




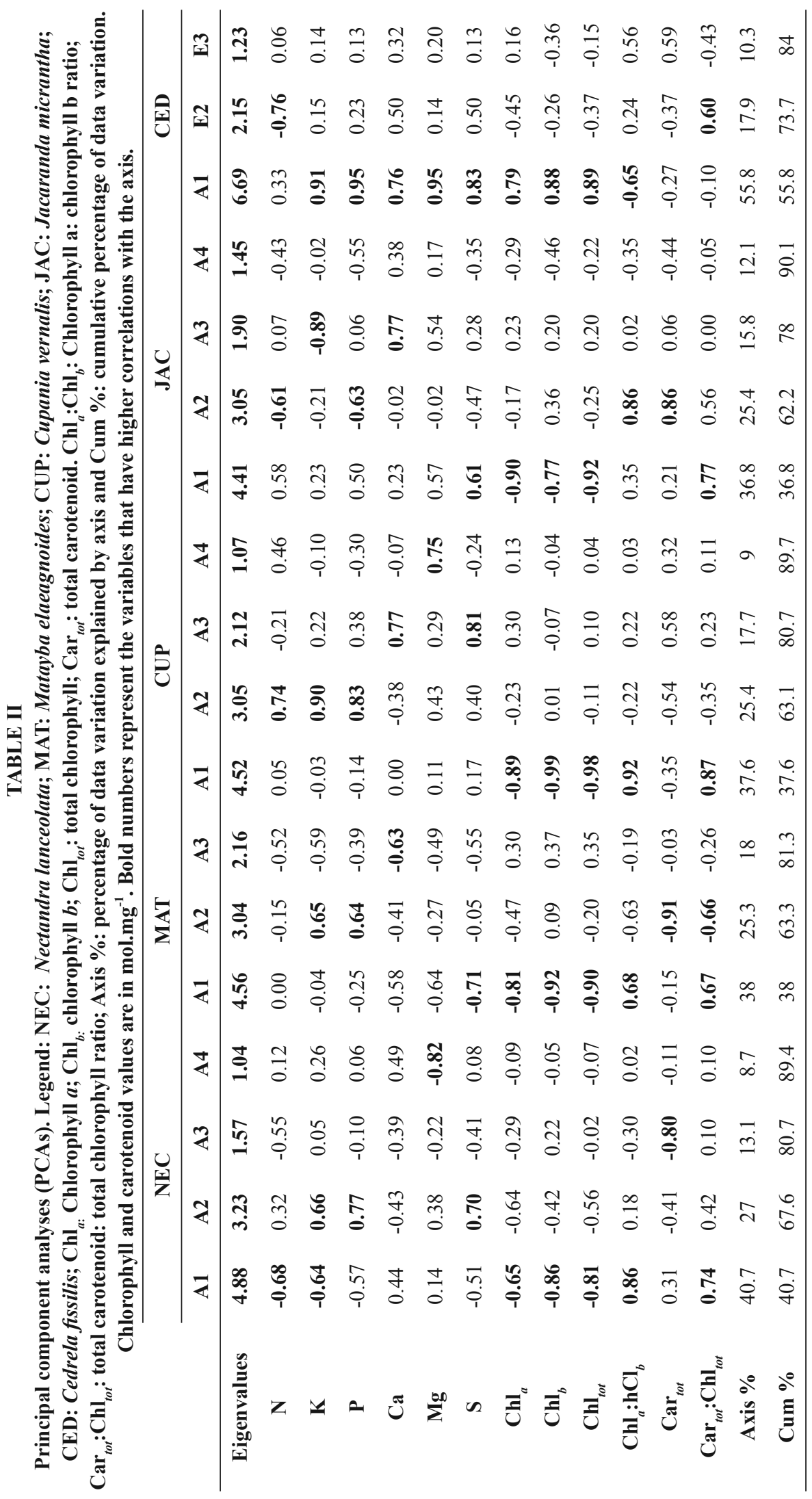


significance related to the scores of the first axis, which is formed primarily by photosynthetic pigments in these species. The three perennial species also showed significant variance for the scores of the second axis, which had $\mathrm{K}$ and $\mathrm{P}$ contribution. In C. fissilis, there were no seasonal differences between the scores of the first two axes, which correspond to $74 \%$ of data variance; the scores of the third axis, however, showed variation during the study period.

\section{TABLE III}

One-way ANOVA (season) made with the scores of the PCA axes that had eigenvalues $>1$ (Kaiser criterion). Legend: SS: sum of squares; DF: degrees of freedom; QM: mean square; $F$ : F values and $P$ : significance.

\begin{tabular}{|c|c|c|c|c|c|}
\hline & & & & & \\
\hline & SQ & GL & $\mathbf{Q M}$ & $\mathbf{F}$ & $\mathbf{P}$ \\
\hline \multicolumn{6}{|c|}{ Nectandra lanceolata } \\
\hline Axis 1 & 10.14 & 3 & 3.37 & 5.48 & 0.009 \\
\hline Axis 2 & 12.01 & 3 & 4.00 & 8.03 & 0.002 \\
\hline Axis 3 & 3.90 & 3 & 1.30 & 1.29 & 0.31 \\
\hline Axis 4 & 1.04 & 3 & 0.34 & 0.29 & 0.83 \\
\hline \multicolumn{6}{|c|}{ Matayba elaeagnoides } \\
\hline Axis 1 & 15.81 & 3 & 5.27 & 20.16 & $<0.001$ \\
\hline Axis 2 & 11.04 & 3 & 3.68 & 6.58 & 0.004 \\
\hline Axis 3 & 4.58 & 3 & 1.53 & 1.58 & 0.23 \\
\hline \multicolumn{6}{|c|}{ Cupania vernalis } \\
\hline Axis 1 & 8.39 & 3 & 2.80 & 3.85 & 0.029 \\
\hline Axis 2 & 14.59 & 3 & 4.86 & 14.37 & $<0.001$ \\
\hline Axis 3 & 0.72 & 3 & 0.24 & 0.20 & 0.89 \\
\hline Axis 4 & 5.67 & 3 & 1.89 & 2.11 & 0.14 \\
\hline \multicolumn{6}{|c|}{ Jacaranda micrantha } \\
\hline Axis 1 & 12.40 & 2 & 6.20 & 28.58 & $<0.001$ \\
\hline Axis 2 & \multicolumn{5}{|c|}{ Kruskal-Wallis $\mathrm{t}=9.5 ; \mathrm{p}=0.008$} \\
\hline Axis 3 & 0.07 & 2 & 0.03 & 0.03 & 0.97 \\
\hline Axis 4 & \multicolumn{5}{|c|}{ Kruskal-Wallis $\mathrm{t}=6.7 ; \mathrm{p}=0.03$} \\
\hline \multicolumn{6}{|c|}{ Cedrela fissilis } \\
\hline Axis 1 & 4.61 & 3 & 2.30 & 2.66 & 0.11 \\
\hline Axis 2 & 5.33 & 3 & 2.67 & 3.31 & 0.07 \\
\hline Axis 3 & 6.24 & 3 & 3.12 & 4.28 & 0.04 \\
\hline
\end{tabular}

\section{DISCUSSION}

In general, the studied species showed high interspecific variation in foliar macronutrient concentration, indicating selective absorption from a common pool in the soil. Chlorophyll and carotenoid concentrations also varied significantly among species and seasons. The correlation between leaf pigments and $\mathrm{Chl}_{a}, \mathrm{Chl}_{b}$ and $\mathrm{Chl}_{\text {tot }}$ with the first axis, which explains most of the data variance, suggests that these parameters change throughout the year for all species. These results allow us to infer that seasonal and climatic variations have an impact on chlorophyll content, although such relation is not similar for all the studied species. Photosynthetic pigments are indicators of the level of plant acclimation to the environment, and for many species there is a consistent relationship 
between pigment content and light (Minotta and Pinzauti 1996). In general, chlorophyll content decreases with increased irradiance, because when there is greater availability of photosynthetic active radiation, photosystems can operate at satisfactory levels for metabolism with less chlorophyll. On the other hand, low irradiance causes chlorophyll content and accessory pigments to increase so as to absorb more light energy and transfer it to reaction centers (Taiz and Zeiger 2013, Zhang et al. 2009). Skillman et al. (1996) observed that leaf chlorophyll content was considerably higher in summer for herbaceous species of deciduous forests. These results, seemingly disparate, may be attributed to metabolic differences between herbaceous and woody plants, as well as to less light availability in the herbaceous layer of deciduous forests in the northern summer, when trees are covered with leaves that prevent light from reaching the interior of the forest.

The balance between chlorophyll and carotenoids is related to plant adaptation to different light conditions, which, in this study, was reflected in the $\mathrm{Car}_{t o t}: \mathrm{Chl}_{t o t}$ ratio. In turn, the $\mathrm{Car}_{\text {tot }}: \mathrm{Chl}_{\text {tot }}$ ratio correlated with the first axis in all species except $C$. fissilis, in which it was correlated with the second axis. According to Rosevear et al. (2001), plants present significant interspecific variation in carotenoid concentration. In addition, as different units are increasingly used to express concentration, different study results should be interpreted with caution. For instance, sun leaves presented higher $\mathrm{Car}_{\text {tot }}$ than shade leaves when the calculation was based on leaf area; however, the contrary was shown based on dry leaf weight (Valladares et al. 2000).

PCA results showed that the nutritional needs of species on the FED/FOM interface differ, showing strong interspecific variation of nutrient contribution to axis formation, which is interpreted as a reflection of different strategies for acquisition, use and conservation of nutrients by forest species.
Interspecific variation in leaf nutrient content has been reported in other studies and interpreted as one of the factors that influences distribution and abundance of forest species, according to their distinct nutritional requirements (Herrera and Finegan 1997, Masunaga et al. 1998).

The leaf nutrient content of the analyzed species in this study was usually similar to or higher than that found in other forest studies (Vitousek and Sanford Jr 1986, Herrera and Finegan 1997, Boeger et al. 2005, Wu et al. 2007). These data suggest that all studied species have the ability to acquire vital elements from the soil, regardless of their phenological pattern (deciduous or perennial). In deciduous species occurring in strongly seasonal environments, leaf senescence generally involves moving nutrients from the leaves to other parts of the plant (Buchanan-Wollaston 1997). However, plants from mesic environments may respond to the changing seasons by dropping their leaves without undergoing drastic physiological alterations, as the main environmental factor that induces leaf senescence is photoperiod change (Fracheboud et al. 2009, Keskitalo et al. 2005).

Previous studies have shown that plants grown in fertile soils or in the later stages of succession have high nutrient concentration in their green and photosynthetic active leaves, and reduced efficiency of nutrient retranslocation from their senescent leaves (Kobe et al. 2005, MartinezSánchez 2005, Yan et al. 2006). It should be noted that the nutritional status of leaves doesn't always correlate with that of the soil, demonstrating that plants with very distinct strategies for acquisition and use of nutrients may coexist.

Nitrogen content was high in the leaves of all species and presented little variation among seasons, which might be interpreted as a reflection of high soil nutrient availability, as argued by Wright et al. (2001), who observed a positive correlation between fertile soils and leaf N. However, N didn't contribute to the formation of the first PCA 
axis in four out of five species, nor did it show correlation with leaf pigments (except $\mathrm{Chl}_{a}$ in $C$. fissilis). Because $\mathrm{N}$ is an element associated with photosynthetic apparatus components, particularly chlorophyll and proteins, this fraction of leaf $\mathrm{N}$ tends to be relatively constant for all species. Positive correlations between leaf $\mathrm{N}$ and chlorophyll have been described, but these relations may vary quite significantly among species, depending on soil availability, efficient use of nitrogen, position of leaf in the canopy and $\mathrm{N}$ allocation to different leaf components (Evans 1989, Kull and Niinements 1998, Hikosaka 2004). The contribution of the other elements in axis formation showed a strong specific characteristic, reflecting once again that, in natural environments, coexisting species may use different metabolic strategies of resource acquisition and use.

In the subtropical forest of southern Brazil, the events most likely to cause temperature and water stress are circumstantial, occurring occasionally throughout the colder and warmer season, respectively (Leite and Klein 1990). Therefore, trees in these forests are not subjected to continuous stress - such as occurs in higher regions, where freezing temperatures are frequent throughout winter; or in dry seasonal forests, which experience a severe period of water stress to which plants respond by altering their metabolic processes. It could therefore be inferred that the variations observed in the plants on the FED/FOM interface are less evident than those of strongly seasonal environments and result in two distinct climate periods, as shown by the PCA graphic representation.

In summary, our results show that there is interspecific variation in the content of leaf photosynthetic pigments and nutrients in tree species occurring on the FED/FOM interface of the subtropical forest in southern Brazil, and this variation is more conspicuous for photosynthetic pigments than leaf nutrients. Of the twelve variables evaluated, photosynthetic pigments, $\mathrm{Chl}_{a}, \mathrm{Chl}_{\mathrm{b}}$ and
Chl tot were particularly important in all species, correlating with the first PCA axis, which explains most of the data and shows that the synchronized changes are not as pronounced as those described in strongly seasonal ecosystems. Leaf pigments are indicators of tree acclimation to seasonal changes.

On the other hand, the contribution of the other variables to axis formation was species-specific that, in terms of leaf nutrients, can be partially attributed to their availability in the soil. This available soil nutrients does not impose limitations to nutrient acquisition and contributes for leaf nutrient concentration to be high and relatively constant throughout the year.

Different strategies for acquisition and use of resources are fundamental for these species to coexist in the forest environment. Our results are important for understanding the nutritional dynamics of subtropical forest ecosystems, considering the different requirements between species, and thereby generate information that will help define strategies for conservation and management of representative fragments of this vegetation.

\section{ACKNOWLEGMENTS}

We are grateful to the Empresa de Pesquisa Agropecuária e Extensão Rural de Santa Catarina (EPAGRI) and to the Centro de Informações Ambientais e de Hidrometeorologia de Santa Catarina (CIRAM) for providing climatic data. We thank Conselho Nacional de Desenvolvimento Científico e Tecnológico (CNPq) for MRT Boeger financial support (process no. 309386/2007-1) and Universidade do Oeste de Santa Catarina (Unoesc) for technical assistance during the field work.

\section{RESUMO}

O objetivo deste estudo foi analisar a variação sazonal no conteúdo foliar de nutrientes e pigmentos em cinco espécies de árvores, sendo três perenes (Cupania vernalis, Matayba elaeagnoides e Nectandra lanceolata) 
e duas decíduas (Cedrela fissilis e Jacaranda micrantha) - em um ecótone entre a Floresta Estacional Decidual e a Floresta Ombrófila Mista em Santa Catarina, Brasil. As amostras de folhas foram coletadas nas quatro estações do ano para determinar o conteúdo de macronutrientes $(\mathrm{N}, \mathrm{K}, \mathrm{P}, \mathrm{Mg}, \mathrm{Ca}, \mathrm{S})$ e pigmentos fotossintéticos $\left(\mathrm{Chl}_{a}\right.$, $\mathrm{Chl}_{b}, \mathrm{Chl}_{t o t}, \mathrm{Car}_{t o t}, \mathrm{Chl}_{a}: \mathrm{Chl}_{b}$ e $\left.\mathrm{Car}_{t o t}: \mathrm{Chl}_{t o t}\right)$. A análise de componentes principais revelou que os pigmentos foliares contribuíram na formação do primeiro eixo, o que explica a maior parte da variação dos dados, para todas as espécies, enquanto a contribuição dos nutrientes mostrou forte variação interespecífica. Estes resultados indicam que as espécies estudadas apresentam diferentes estratégias para aquisição e uso dos recursos minerais e aclimatação à luminosidade, as quais são fundamentais para sua coexistência no ambiente florestal.

Palavras-chave: clorofila, floresta com Araucária, Floresta Decidual, macronutrientes.

\section{REFERENCES}

BOEGER MRT, WISNIEWSKI C AND REISSMANN CB. 2005. Nutrientes foliares de espécies arbóreas de três estádios sucessionais de floresta ombrófila densa no sul do Brasil. Acta Bot Bras 19(1): 167-181.

BUCHANAN-WOLLASTON V. 1997. The molecular biology of leaf senescence. J Exp Bot 48(2): 181-199.

BÜNDCHEN M, BOEGER MRT AND REISSMANN CB. 2013. Status nutricional e eficiência no uso de nutrientes em espécies arbóreas da floresta subtropical no sul do Brasil. Scientia Forestalis (IPEF) 41: 227-236.

CARVAlHo APF, Bustamante MCC, Kozovits AR AND ASNER GP. 2007. Variações sazonais nas concentrações de pigmentos e nutrientes em folhas de espécies de cerrado com diferentes estratégias fenológicas. Rev Bras Bot 30(1): 19-27.

CHAPIN III FS. 1980. The mineral nutrition of wild plants. Annu Rev Ecol Syst 11: 233-260.

Dos SANTOS HG, JACOMINE PKT, Dos ANJOS LHC, DE OLIVEIRA VA, DE OLIVEIRA JBD, COELHO MR, LUMBRERAS JF AND CUNHA TJF (EDS). 2006. Sistema brasileiro de classificação de solos. Rio de Janeiro: Embrapa Solos, $353 \mathrm{p}$.

EVANS JR. 1989. Photosynthesis and nitrogen relationships in leaves of $\mathrm{C}_{3}$ plants. Oecologia 78(1): 9-19.

FRACHEBOUD Y, LUQUEZ V, BJÖRKÉN L, SJÖDIN A, TUOMINEN H AND JANSSON S. 2009. The Control of Autumn Senescence in European Aspen. Plant Phys 149(4): 1982-1991.

GRIME JP. 1977. Evidence for the existence of three primary strategies in plants and its relevance to ecological an evolutionary theory. Am Nat 111: 1169-1195.
HERRERA B AND FINEGAN B. 1997. Substrate conditions, foliar nutrients and the distributions of two canopy tree species in a Costa Rican secondary rain forest. Plant Soil 191(2): 259-267.

HIKOSAKA K. 2004. Interspecific difference in the photosynthesis-nitrogen relationship: patterns, physiological causes, and ecological importance. J Plant Res 117(6): 481-494.

IBGE - INSTITUTO BRASILEIRO DE GEOGRAFIA E ESTATÍSTICA. 1990. Mapa da vegetação brasileira. Rio de Janeiro, $271 \mathrm{p}$.

JOHNSON RA AND WICHERN DW. 1998. Applied multivariate statistical analysis. New Jersey: Pearson Prentice Hall, $773 \mathrm{p}$.

KESKITALO J, BERGQUIST G, GARDESTRÖM P AND JANSSON S. 2005. A Cellular Timetable of Autumn Senescence. Plant Phys 139(4): 1635-1648.

KLEIN RM. 1978. Mapa fitogeográfico do estado de Santa Catarina. Edited by Reitz R (Org), Flora Ilustrada Catarinense. Itajaí: Herbário Barbosa Rodrigues, 24 p.

KOBE RK, LEPCZYK CA AND IYER M. 2005. Resorption efficiency decreases with increasing green leaf nutrients in a global data set. Ecology 86: 2780-2792.

Kull O AND NiINEMETS Ü. 1998. Distribution of leaf photosynthetic properties in tree canopies: comparison of species with different shade tolerance. Funct Ecol 12(3): 472-479.

LEITE PF. 2002. Contribuição ao conhecimento fitoecológico do sul do Brasil. Ciência e Ambiente 24: 51-73.

LEITE PF AND KLEIN RM. 1990. Vegetação. Geografia do Brasil: Região Sul. Instituto Brasileiro de Geografia e Estatística (IBGE) 2: 113-150.

LiCHTENTHALER HK AND WELlbuRN AR. 1985. Determination of total carotenoids and chlorophylls $a$ and $b$ of leaf extracts in different solvents. Biochem Soc T 11: 591-592.

MARTÍNEZ-SÁNCHEZ JL. 2005. Nitrogen and phosphorus resorption in a neotropical rain forest of a nutrient-rich soil. Rev Biol Trop 53(3-4): 353-359.

MASUNAGA T, KUBOTA D, HotTA M AND WAKATSUKI T. 1998. Nutritional characteristics of mineral elements in leaves of tree species in tropical rain forest, West Sumatra, Indonesia. Soil Sci Plant Nutr 44(3): 315-329.

MINOTTA G AND PINZAUTI S. 1996. Effects of light and soil fertility on growth, leaf chlorophyll content and nutrient use efficiency of beech (Fagus sylvatica L.) seedlings. For Ecol Manage 86(1): 61-71.

Pierce S, Vianelli A AND Cerabolini B. 2005. From ancient genes to modern communities: the cellular stress response and the evolution of plant strategies. Funct Ecol 19(5): 763-776.

POORTER L. 2009. Leaf traits show different relationships with shade tolerance in moist versus dry tropical forests. New Phytol 181(4): 890-900. 
PORRA RJ, THOMPSON WA AND KRIEDERMANN PE. 1989. Determination of accurate extinction coefficients and simultaneous equation for assaying chlorophylls a and b extracted with four different solvents: verification of the concentration of chlorophylls standards by atomic absorption spectroscopy. Biochim Biophys Acta 975(3): 384-394.

RAIMUNDO MG. 2003. Estudo do processo de criação de uma unidade de conservação no vale do Rio do Peixe, SC. Dissertação, Centro de Ciências Tecnológicas, Universidade Regional de Blumenau, Blumenau, 80 p.

RoSEVEAR MJ, YOUNG AJ AND JOHNSON GN. 2001. Growth conditions are more important than species origin in determining leaf pigment content of British plant species. Funct Ecol 15(4): 474-480.

RUSCHEL AR, NODARI RO AND MOERSCHBACHER BM. 2007. Woody plant species richness in the Turvo State park, a large remnant of Deciduous Atlantic Forest, Brazil. Biodivers Conserv 16: 1699-1714.

SKILlman JB, STRAIN BR AND OSMOND CB. 1996. Contrasting patterns of photosynthetic acclimation and photoinhibition in two evergreen herbs from a winter deciduous forest. Oecologia 107(4): 446-455.

TAIZ L AND ZEIGER E. 2013. Fisiologia Vegetal. Porto Alegre: Artmed, $954 \mathrm{p}$.
VAlladares F, MARTineZ-FERri E, BALAGUER L, PEREZCORONA E AND MANRIQUE E. 2000. Low leaf-level response to light and nutrients in Mediterranean evergreen oaks: a conservative resource-use strategy? New Phytol 148(1): 79-91.

VITOUSEK PM AND SANFORD JR RL. 1986. Nutrient cycling in moist tropical forest. Annu Rev Ecol Syst 17: 137-167.

Wright IJ, REICH PB AND WESTOBY M. 2001. Strategy shifts in leaf physiology, structure and nutrient content between species of high- and -low rainfall, and high and low nutrient habitats. Funct Ecol 15: 423-434.

Wu CC, TSui CC, Hsein CF, Asio VB AND CHEN ZS. 2007. Mineral nutrient status of tree species in relation to environmental factors in the subtropical rain forest of Taiwan. For Ecol Manage 239(1-3): 92-101.

YAN E, WANG X AND HUANG J. 2006. Shifts in plant nutrient use strategies under secondary forest succession. Plant Soil 289: 187-197.

ZAR JH. 1999. Biostatistical analysis. New Jersey: Pearson Prentice-Hall, 960 p.

ZHANG LL, WEN DZ AND FU SL. 2009. Responses of photosynthetic parameters of Mikania micrantha and Chromolaena odorata to contrasting irradiance and soil moisture. Biol Plant 53(3): 517-522. 